\title{
The role of partisan cues on voters' mobilization in a referendum
}

\author{
Miroslav Nemčok \\ Peter Spáč \\ Petr Voda \\ Masaryk University \\ Masaryk University \\ Masaryk University
}

\begin{abstract}
Even though partisan cues are widely recognized as a primary force shaping voter behavior in a referendum, their effect on a decision whether to attend or abstain from voting has not yet been carefully studied. Our analysis of the pre-referendum survey data gathered before the 2015 citizen-initiated referendum in Slovakia leads to two important conclusions: First, parties' recommendations whether to attend or abstain from voting influence voters' behavior in a similar fashion as their suggestions for which side to vote for. Moreover, in certain institutional settings, the partisan cues related to mobilization have an even stronger impact on voters than endorsements for who or what to vote for. Second, the provided party recommendations must be unambiguous and clear. Lower clarity cues are reflected in voters' behavior to a lesser extent.
\end{abstract}

Keywords: referendum; mobilization; party cues; clarity; Slovakia;

This article has been published in Contemporary Politics 2019, 25(1): 11-28. 


\section{Introduction}

The complexity of every referendum issue goes far beyond the question stated on the ballot. Therefore, voters often gladly respond to cues from familiar political parties and let the cues guide them through a complex, information-rich environment to a simple 'yes' or 'no' answer on the ballot (De Vreese \& Semetko, 2004; Lupia \& McCubbins, 1998; Zaller, 1992). The influence of voting recommendations made by a preferred party on a voter's decision of which side to vote for has been empirically documented by numerous studies (Cini, 2004; Franklin, Marsh, \& McLaren, 1994; Franklin, Marsh, \& Wlezien, 1994; Hobolt, 2006, 2007; Hug \& Sciarini, 2000; Pierce, Valen, \& Listhaug, 1983). Moreover, partisan cues seem to influence voters' behavior across various contexts to a sufficient degree that they can substantially contribute to a referendum's success (Silagadze \& Gherghina, 2017).

However, while the impact of partisan cues on voting has been extensively studied, their influence on voters' decisions to turn out has remained excluded from the focus of researchers. This is rather surprising, given the fact that in some institutional settings, the decision to abstain from voting may be a strategic choice and effective means to invalidate a referendum, which was e.g. the case of the 2012 referendum in Romania (Gherghina \& Miscoiu, 2013).

Especially in the CEE region, parties are willing to 'hijack' the referendums to improve their own position in political struggles instead of using them as a way to increase the public engagement of citizens in the democratic system (Gherghina, 2018). Therefore, it is relevant to study the impact of partisan cues because they may largely determine the outcomes of a popular vote, which may serve as a means for parties to achieve their selfish goals and expand their own power.

This article seeks to partially fill this gap by analyzing the 2015 'Family' referendum held in Slovakia. The choice of country lies in both in its rich experience with referendums as 
well as in its institutional setting. Since its emergence in 1993, Slovakia has held eight referendums. Its legal rules require a fifty percent turnout for a referendum to be valid. Given such a threshold, opponents of a referendum have utilized a strategy of demobilizing their supporters, and have thus effectively lowered the turnout. Hence, turnout is the crucial factor in Slovak referendums, and only one has successfully passed so far (Nemčok \& Spáč, 2018).

The 2015 Slovak referendum issues, initiated by a non-party actor, dealt with the rights of sexual minorities. The highly religious Slovak society was clearly polarized by this issue, as three out of every four people identify with some religious denomination, while a considerable majority (roughly 62\%) of the whole population consider themselves Catholics (Statistical Office of the Slovak Republic, 2011). But the topics related to sexual minorities do not clearly divide the Slovak political representation and therefore a variation in the degree to which political parties provided voters with straightforward recommendations about how and if to turn out to vote could be observed. Some political parties took a clear stance, while others were hesitant to do so and provided little if any recommendation. These varying levels of clarity in parties' endorsements unlocked an opportunity to study how the level of clarity influences the impact of partisan cues when it comes to a voter's decision to attend or abstain from voting in a referendum.

This paper uses the data collected in an original pre-referendum representative survey. Through a series of statistical tests, it aims to study the effect of partisan cues on the mobilization of voters in a referendum and how the effect varies in relation to the ambiguity of an endorsement. Our results suggest that the party cues related to mobilization influence voters in a similar fashion compared to cues recommending which side to vote for. Moreover, the clearer the cue, the bigger its influence. But most importantly, voters who vote are more autonomous of their party's recommendation. Therefore, a party's call to mobilize constitutes 
a critical force in shaping referendum outcomes, because it influences the behavior of voters who are more inclined to follow the cues put forth by their preferred party.

The next section sums up the recent knowledge about the impact of partisan cues and the conditions which determine their effects. Subsequently, the research design and data employed, as well as the context of the 2015 Slovak 'Family' referendum, are presented. The last section contains the results of the empirical analysis. The section is followed by a discussion about the institutional regulations that determine when the party's call to attend or abstain from voting becomes more popular than the recommendation of which side to vote for.

\section{Complexity of referendum issues and the role of cues}

Voting in a referendum means choosing an answer from two dichotomous options provided on a certain question. As an act, it seems quite simple. However, behind a ballot paper, there are hidden comprehensive dilemmas which require a fair deal of intermediate sub-decisions in order to arrive at a simple-looking 'yes' or 'no' (De Vreese \& Semetko, 2004; Lupia \& McCubbins, 1998). Referendums deciding about the issues related to the European Union represent great examples. In the case of the Brexit referendum, the question itself consisted of sixteen words. However, for a qualified decision one needed to understand a colossal number of agendas influenced by the European Union as well as the possible impacts on the future economic, political and societal development of the United Kingdom. Indeed, not all referendums are as comprehensive as the European ones, and the referendum about family analysed here is an example, but every single one expects that a voter is familiar with issues reaching far beyond the actual referendum question (Altman, 2011; Hobolt, 2007, p. 155; LeDuc, 2009; Lupia \& Johnston, 2001).

The complexity of the topic may easily become a source of confusion and uncertainty for voters. Pre-referendum discourse packed with contradictory messages and mutually 
exclusive projections of future development even worsen the whole situation. Therefore, it is unsurprising that voters gladly grab the familiar cues and allow them to guide their decisionmaking process (Lupia \& McCubbins, 1998). The endorsement of a certain referendum outcome by a preferred party (or its leader) is exactly the kind of cue that provides the electorate with clear directions through a confusing media space and hard-to-predict policy implications.

Kriesi (2005) and Sager and Bühlmann (2009) confirmed that the higher familiarity of voters with the referendum topic increases the probability of their turnout at the polls. The reason is that the cues increase the availability of information in the public space and make it easier for voters to make up their minds (Font \& Rodríguez, 2009). Therefore, if parties approach a referendum actively, clearly formulate their stances and add the ideological bases to the referendum topic, their activities make the voters' decision-making processes less demanding, which increases the probability that voters will turn out to vote. On the contrary, lack of partisan cues and blurred ideological standpoints result in high volatility (LeDuc, 2009) and poor party performance in mobilizing its own supporters (De Vreese \& Semetko, 2004).

It may be argued that the story is rather the other way around and it is not a partisan cue that comes first and drives the voters' behavior, but it is instead popular demand that determines the cues, because parties want to stay consistent with the preferences of their supporters. However, this is highly unlikely. The thing is that voters tend to enter already initiated referendum campaigns with 'relatively weak predispositions and low levels of information' (LeDuc, 2009, p. 158). Therefore, it is basically impossible for parties to have sufficiently accurate estimates of their supporters' positions on the issue to position themselves before the campaign starts (Pierce et al., 1983). Moreover, while parties hold their positions more or less constant throughout the whole campaign, voters are more likely to shift 
their opinion in order to follow a partisan cue (Jenssen \& Listhaug, 2001, p. 190).

Furthermore, a canon of case studies confirms that partisan attachments serve as a primary force in referendum voting and constitute a strong and consistent predictor of a voter's final decision (Cini, 2004; Franklin, Marsh, \& McLaren, 1994; Franklin, Marsh, \& Wlezien, 1994; Hug \& Sciarini, 2000; Pettersen, Jenssen, \& Listhaug, 1996; Pierce et al., 1983). Therefore, following the literature, we also expect that the cues are closer to being the independent factor influencing voter behavior in a referendum campaign.

\section{Factors determining the impact of partisan cues}

Even though the influence of partisan cues on voter behavior has been widely recognized for quite some time, the field has undergone substantial development. During the 1970s, partisan cues were considered to be a direct power influencing voter mobilization and choices to a very large extent (e.g. McKelvey \& Ordeshook, 1986). However, as time goes by, further contextual conditions are being added - such as political environment and the characteristics of actors giving and receiving the cue (e.g. Lupia \& McCubbins, 1998), and the link between a cue and a voter has become less straightforward and more blurred (Hug \& Sciarini, 2000). The following section presents the development and describes the additional factors that facilitate the actual impact of party cues on a voter's decision to attend or abstain from a referendum voting.

\section{Individual determinants}

Quite naturally, the impact of a cue on the decision to attend or abstain from voting does not have constant impact across the whole electorate. Even though a cue can in theory influence any voter, it is the power of partisanship that facilitates its actual impact. As argued by Borges and Clarke (2008, p. 445), it is 'the interaction with political predisposition towards a cuing party or political leader that generates theoretically plausible and statistically significant 
results'. Therefore, partisans and party supporters are exactly those actors, in particular, whose decisions about participation and voting are primarily driven by cues provided by the parties and leaders they prefer (Borges \& Clarke, 2008; Zaller, 1992).

However, it may be expected that some of an individual's characteristics that influence the decision-making process could be triggered by the referendum topic and override the impact of partisan cues. This is especially the case for controversial issues related to e.g. the rights of sexual minorities, which can stimulate personal prejudices such as homophobia and can impact how an individual will vote. However, the link between prejudices and voting does not seem to be straightforward and nor does it completely override the cues. Empirical research studying same-sex marriage referendums in the USA identified, on an aggregate, a strong link between party affiliation or party vote shares and support for same-sex marriage (Camp, 2008; McVeigh \& Diaz, 2009). The same holds true for the 2013 Croatian Referendum on the Constitutional Definition of Marriage, whose cultural context is much closer to the case of the Slovak 'Family' referendum. Based on originally collected aggregatelevel data from the 2013 referendum in Croatia, Glaurdić and Vuković concluded (2016, p. 803) that ' $[\mathrm{c}]$ ontrary to popular interpretations, $[\ldots]$ the referendum results primarily reflected the pattern of support for the two principal electoral blocs, rather than communities' traditionalist characteristics or grievances stemming from economic adversity.' These studies indicate a strong connection between partisanship and support for or voting in a referendum. Thus, we may reasonably expect that if prejudices influence the impact of partisan cues, it happens in the beginning by determining voters' partisanship inclinations. As an intervening factor, the partisanship mediates the connection between prejudices and voting by making voters more attentive to the cues sent by the preferred party, which therefore have more influence on voter decisions. 
In addition to interacting with partisanship, cues also affect a voter's political awareness. The voters with a high level of political awareness tend to be more independent of the partisan cues and prioritize their own attitudes towards a topic (Hobolt, 2005). On the contrary, the ill-informed voters tend to be more inclined to follow the parties' recommendations, even though it can drive them to cast a vote that is further away from their own preferences (Hobolt, 2007). Even though both of Hobolt's $(2005,2007)$ abovementioned conclusions were actually related to voting, her observations are important for referendum turnout as well. Even among partisans, we should expect that higher levels of a voter's political knowledge will result in greater decision-making autonomy. Hence, a cue recommending (de)mobilization has a bigger impact among less politically knowledgeable partisans compared to their counterparts with higher levels of political awareness.

\section{Clarity}

Like voters, partisan cues are far from being uniform. While some parties unambiguously and repeatedly state their recommendations on whether to attend a plebiscite or not, others can be internally divided, which may result in a tentative or not-entirely-clear recommendation. The literature specifically mentions that '[...] for partisanship to have maximum impact, the parties must take clear and uniform positions on the issue at stake. When the parties divide, so do their followers' (Pierce et al., 1983, p. 61). With the mixed or unclear messages, parties perform poorly in mobilizing their own supporters, not to mention the rest of the electorate (De Vreese \& Semetko, 2004).

However, the level of a cue's clarity must be perceived as a party's conscious strategy. It's decision to emphasize or blur its recommendation simply reflects intra-party struggles, heterogeneity of the party's electorate in relation to the referendum topic or the party's position on issue dimensions within the political competition (Rovny, 2012). Since voters gladly consume easily available information in the referendum campaign (Font \& Rodríguez, 
2009), which cues clearly are, it is the strategic blurring and ambiguous recommendations that partially cause voters to often complain of there being 'insufficient information' throughout the referendum process (LeDuc, 2009) and that they lack an important guide through the referendum campaign (Hobolt, 2006).

Therefore, a clear cue is more efficient in facilitating a voter's orientation in a prereferendum campaign and influencing a voter's decision whether to attended or abstain from voting in a referendum to a higher degree compared to an ambiguous recommendation.

\section{Institutional determinants}

Regardless of the issue, a referendum is part of politics and, consequently, must be perceived as a struggle among political actors. Therefore, a referendum that manages to mobilize a sufficient portion of the electorate in order to become valid, not only has implications for the future development of a common polity, but moreover divides parties into winners and losers in accordance with their initial pre-referendum position. This is how referendums are perceived from the 'second-order' perception (Silagadze \& Gherghina, 2017), which claims that they constitute an additional means for voters to punish or reward the parties for their performance (Franklin, Marsh, \& McLaren, 1994; Franklin, van der Eijk, \& Marsh, 1995). Therefore, satisfaction with elected representatives is another key factor determining whether voters turn out the vote, if (de)mobilization is already a legitimate means of expressing one's (dis)satisfaction.

According to Hug and Sciarini (2000), there are three institutional features which mediate the impact of partisanship on mobilization and voting behavior and therefore influence the strength of partisan cues: '[1] whether the referendum is required, [2] whether the people's decision has a binding character, or [3] which government coalition is presently in power'. These aspects mainly determine the importance of a referendum and, consequently, 
(de)mobilization can reflect the condemnation of or a "vote of confidence in" the government/political representation.

\section{Research design}

The 2015 'Family' Referendum in Slovakia constitutes a great case to study the effect of partisan cues on voters' behavior mainly for three reasons: First, the referendum was initiated through a plebiscite and by a non-party actor. Moreover, thanks to rather controversial topics regarding the rights of LGBT community, none of the parties tried to 'kidnap the plebiscite' in order to steal the spotlight and gain popular support. The referendum did not turn into an inter-party clash that could significantly shape the perception of the referendum among voters (Cini, 2004), but remained an act initiated by an NGO with no direct affiliation to any political party. Second, given its topic, the 'Family' referendum was non-required, with basically no biding incentives for any of the political actors. In this aspect, the plebiscite dealt only with the initial topic. Therefore, voters had basically no reason to perceive the referendum as a 'second-order' opportunity to punish or reward the parties. These two aspects ensure that the above-stated institutional determinants remain constant and allow us to study the general impact of partisan cues on mobilization in a referendum. Third, the political parties decided to implement low profile strategies in the campaign (Rybář \& Šovčíková, 2016). Therefore, if we can find substantive evidence confirming the impact of partisan cues on mobilization where parties kept a low profile, there is no doubt that an even stronger impact can be expected in cases of referendums where parties played a more significant role.

Besides that, the controversial topic had additional positive externality: alongside those who openly declared their recommendations for voting behavior, there were parties hesitant to take a clear stance because their electorates came from Christian clusters as well as from more liberal segments of society. This also provided us with a variation in the ambiguity of parties' endorsements and allowed us to study another important attribute of cues 
specifically emphasized by Pierce, Valen, and Listhaus (1983) - the clarity of the recommendation.

\section{Data and Methods}

The effect of partisan cues on mobilization in a referendum is tested on the dataset resulting from a public survey which was conducted by FOCUS Agency on behalf of the Slovak Daily newspaper SME. Data collection took place between 20-26 January 2015, i.e. roughly two weeks before the referendum was held on 7 February 2015. FOCUS Agency collected data on a representative sample (1,070 respondents) of the general Slovak population. To the best of our knowledge, this is the only representative data that was gathered in regard to the 2015 'Family' referendum.

The survey included six questions plus a basic set of sociodemographic characteristics (i.e. gender, age, education, and income). The first question aimed to find out the probability that a respondent would turn out to the referendum. A set of three questions followed the exact wording of the questions used in the actual referendum and was intended to identify respondents' opinions on the referendum topics. The next question was aimed at respondents' partisanship inclinations and thus it asked respondents which party they would vote for if the legislative elections were held during the upcoming weekend. The last question asked about attitude towards religion and offered five options: (a) deeply religious, (b) religious, (c) not decided, (d) not religious, (e) atheist. Since the topics dealing with the rights of sexual minorities were especially controversial within more conservative circles, this question was supposed to control for the level of religiosity among respondents and we will be referring to this characteristic as 'faith'.

Our analysis consists of two parts. The first one is focused on mobilization and examines whether voters acted consistently with the recommendation of their preferred party 
and attended the referendum or abstained. ${ }^{1}$ The second part inspects the actual voting and analyzes whether voters voted consistently with the recommendation made by their favored party for each of the questions. Thus, one item focused on mobilization and three items dealing with the three referendum topics give us a total set of four dependent variables for the analysis. Each variable is binary, with value one given to voters whose intended vote in the pre-referendum public opinion poll, when compared, corresponded to their favored party's cue and zero if it did not.

Our main independent variable is the clarity of a partisan recommendation. For this purpose, we divided parties' recommendations into three groups according to the level of their clarity, as follows:

Clarity 1: Official statement of the party or its leadership body

Clarity 2: Official stance of the party leader, which is opposed by some party members

Clarity 3: No official statement. However, the party leader unofficially shared his/her stance with the media (without any confirmation from the internally divided party base)

We tracked the clarity of partisan cues separately for attending the referendum (or abstaining from such voting) and voting on the referendum questions. The data however did not allow us to distinguish clarity of partisan recommendation for each of the referendum questions but only en bloc for all three questions. The coding of clarity of partisan suggestion is listed in Table A.1 in Online Appendix A.

Besides the independent variables, we apply a set of controls. These consist of basic sociodemographic voter characteristics that might shape their behavior regarding the

1. Share of party supporters in the sample and the distribution of their declared probability to attend the referendum are presented in Table B.1 included in Online Appendix B. 
referendum in practice. First, we included gender as a binary variable with value one given to women and value zero to men. We further cover education. This variable is coded into an ordinal scale ranging from one to four, with each category given to a type of obtained education degree (e.g. elementary, lower secondary, higher secondary, university), thus the higher values indicate a person's higher education. The third control is income. This variable is also coded as categorical on a seven-point scale from one to seven with higher values indicating higher income. After that we include age (logged), and finally, the level of faith on a five-point scale ranging from one to five with higher categories indicating stronger religious status. Religious belief can be also seen as proxy for homophobia since it has been found as factor explaining homophobia in previous studies (see e.g. Adamczyk \& Pitt, 2009; Besen \& Zicklin, 2007; Brewer, 2003; Haider-Markel \& Joslyn, 2005). We provide some further arguments for the usage of this variable in the Slovak context in Online Appendix C.

The analysis was conducted on the individual level while the focus was placed on the consistency between a respondent's reported decision and the recommendation of the party they declared they would vote for if the election were to take place the next weekend. We excluded two subsets of respondents: (1) those who declared no party preference and (2) those whose preferred party made no recommendation for mobilization or voting. ${ }^{2}$ The first restriction respects the current research that has confirmed that party cues have an effect on its own supporters (Borges \& Clarke, 2008; Zaller, 1992). Our data was collected roughly two months after the 2014 municipal election. Since individuals within an 'electoral cycle' are more inclined to state their partisan preferences shortly after the elections (Andersen, Tilley, \& Heath, 2005; Arceneaux, 2005; Stevenson \& Vavreck, 2000), the proximity of the last municipal election may explain the overrepresentation of people stating their party preference (which goes up to 75\%). Therefore, despite a large number of respondents stating their party

2. For information about coding see Online Appendix A. 
preference, we may still reasonably expect that by focusing on respondents who declared their party preference we can examine the effect of partisan cues on party supporters.

To analyze the consistency of voters with partisan recommendations dealing with attending or abstaining from voting on the referendum we use data from all respondents with the exception of the two groups mentioned above. However, for examining the effects of partisan cues on voting on each of the referendum questions, we restrict the dataset only to respondents who stated that they would attend the referendum. In the pre-referendum survey we use, respondents were asked to declare a percentage probability they would attend the referendum. As attendees we understand those respondents who reported a probability to attend the referendum at $70 \%$ or higher. ${ }^{3}$

For examining the effect of clarity of partisan cues on turnout in a referendum we use probit analysis. For this part of the analysis, we use only those respondents that declared they would attend the referendum. This group however cannot be understood as a randomly selected subset of all respondents, which can lead to biased results (Hug, 2003). Therefore, to deal with such selection bias we employ two-stage models based on probit regression analysis, also known as the Heckman correction (Heckman, 1979). Given the available data and its structure, this method is the most suitable for our analysis (c.f. Bodenstein $\&$ Kemmerling, 2011). For correcting the selection bias, we use the controls in the first stage model (i.e. turnout). Heckman correction requires at least one variable affecting the dependent variable to be included in the selection equation while being omitted in the second stage of the model. To follow this requirement, the control covering faith is dropped from the second

3. This is due to overestimation of declaration of respondents to attend referendums and their real willingness to do so as was found in previous referendums. Although, we ran the analysis with thresholds of $50 \%$ and $60 \%$ with roughly the same results. 
stage of the models. We selected this variable as we found it to be a strong predictor of the turnout to the referendum.

\section{Context of the 2015 'Family' Referendum}

Slovakia represents a case with an established tradition of referendum employment. Since the country's emergence in 1993, eight referendums have been held, which makes the Slovak political system fairly familiar with the institution, even though there is only one case - EU accession - when a referendum ended up valid (Spáč, 2010). The reason for such a low number of successes is the strict institutional framework, which sets two challenging conditions that must be met for a referendum to be successful: (1) At least $50 \%$ of the registered electorate plus one voter must attend the poll and (2) a simple majority of attending voters must decide for one of the answers provided. ${ }^{4}$ Under such conditions, the turnout in most Slovak referendums was well below the required 50\%. The lowest turnout occurred in 1997, with less than 10\% turnout, while the highest turnout (except for the EU accession referendum) was achieved in the 1998 referendum on banning the strategic privatization of state property, when $44.3 \%$ of voters showed up at the polling stations. It is important to note that the turnout generally increases if the referendum coincides with elections. So far, referendums were twice held on the same day as either a general or a presidential election, in 1998 and 2004, and they saw a turnout of $44.3 \%$ and 35.9\%, respectively. On the other hand, the mean turnout of the other six referendums was only around $24 \%$, and if the EU accession referendum is excluded this number decreases to under $19 \%$. Hence, in terms of level of turnout, the timing of the referendum is of high importance.

4. This may sound like a redundant condition, however, if the 'yes' and 'no' camps are roughly the same size and there is a substantial share of voters submitting an empty ballot, it can invalidate a referendum. 
In Slovakia, the referendums are most often initiated by political parties in the pursuit of their own interests (Nemčok \& Spáč, 2018). However, the 2015 referendum represents an exception from this pattern, because it was initiated by the civic association Alliance for Family. The Alliance itself was established in 2013 with the mission to protect conservative values, especially the values related to the 'traditional' family. It operates as an umbrella structure for more than 100 mostly Christian organizations and associations dealing with social care, healthcare and other similar issues. Even though the Alliance put significant effort into presenting itself as an independent organization, its strong financial and personal ties to the Catholic church in Slovakia were undeniable (Kováč, 2015). Besides providing financial support, the Church used its dense network of churches and communities to raise awareness about the referendum and encouraged people to attend the vote (Smrek, 2015).

In the spring of 2014, the Alliance started a petition to hold a referendum about family issues and managed to collect well above the 350,000 signatures, as required by Article 95 of the Slovak Constitution. Soon after the signatures were delivered to the Slovak President, Andrej Kiska, he exercised his legal power to approach the Constitutional Court to ensure that the proposed questions did not violate constitutional law. The original petition initiated by the Alliance for Family included four questions. However, two months after being officially approached by the President, on 28 October 2014, the Constitutional Court ruled that one of the four proposed questions was unconstitutional, citing that it dealt with basic human rights and freedoms, which cannot be put to a referendum vote (Rybář \& Šovčíková, 2016). ${ }^{5}$ The elimination of only one question came as a surprise to the President, who repeatedly stated his

5. Full wording of the excluded question was: Do you agree that no cohabitation of persons other than those who are married should be granted the particular protections, rights and duties that the legislation as of 1 March 2014 granted only to marriages between a husband and wife; in particular, the acknowledgement, registration or recording as a lifelong partnership in front of a public authority, and the opportunity to adopt a child by the spouse of a parent? 
personal doubts regarding the constitutionality of the issues, and once directly, on the occasion of the official announcement of the date of the referendum (Cuprik, 2014). Nevertheless, he honored the Constitutional Court's ruling and called the referendum on 7 February 2015. It contained the following three questions:

(1) Do you agree that no other cohabitation of persons other than a bond between one man and one woman can be called marriage?

(2) Do you agree that same-sex couples or groups shouldn't be allowed to adopt children and subsequently raise them?

(3) Do you agree that schools cannot require children to participate in education pertaining to sexual behaviour or euthanasia if the children or their parents don't agree?

Although the Alliance proclaimed the referendum to be about the protection of family, two of the three questions dealt with same-sex marriages and a ban on the adoption of children by same-sex couples. Given that the majority of Slovak citizens declare themselves to be Catholics, ${ }^{6}$ these topics clearly had the potential to polarize society as well as political parties. Basically, all relevant political parties declared their position on the referendum. Moreover, they not only provided voters with a recommendation on how to vote on a particular question, but also whether to attend the popular vote (see Online Appendix A). The endorsement of a participation strategy must be perceived within a broader picture of the Slovak institutional setup. Obviously, the referendum topic was important for more conservative segments of the society. Since the majority of Slovaks recognize themselves as

6. Based on the data from Population Census 2011, the share is more than $62 \%$ of the population and there are more religious groups with significant representation (Statistical Office of the Slovak Republic, 2011). 
Catholics, it could be expected that these societal groups would attend the referendum and would vote 'yes' on the three referendum questions. Moreover, the first surveys on the referendum topic, conducted long before the referendum, revealed that a majority of the Slovak population supported the ideas promoted by the Alliance for Family. However, credible information on the estimated attendance was absent. In such a situation, the parties opposing the referendum recommended abstention from voting. Given the required turnout threshold of $50 \%$ and the expected predominance of those who attend the voting to cast a 'yes' vote, this strategy was more effective. The logic is quite straightforward, as abstaining from voting effectively reduces the turnout without any need to outnumber the mobilized 'yes' camp.

Despite an emotional campaign full of conflicts between representatives of the Church and the LGBTQ community (see Rybáŕ \& Šovčíková, 2016; Smrek, 2015), the turnout on the referendum reached only $21.4 \%$ (see Table 1), well below the required threshold. Hence, similarly to majority of referendums that have been conducted in Slovakia, the 2015 'Family' Referendum ended up invalid too.

Table 1. Results of the 2015 'Family' Referendum in Slovakia

\begin{tabular}{lrrcccc}
\hline \multicolumn{1}{c}{ Question } & \multicolumn{1}{c}{ Yes } & \multicolumn{1}{c}{ No } & $\begin{array}{c}\text { Invalid/ } \\
\text { blank }\end{array}$ & Total votes & $\begin{array}{c}\text { Registered } \\
\text { voters }\end{array}$ & Turnout \\
\hline 1: Marriage & $94.5 \%$ & $4.13 \%$ & 12,867 & & & \\
& $(892,719)$ & $(39,088)$ & & & & \\
2: Adoption & $92.43 \%$ & $5.54 \%$ & 19,061 & 944,674 & $4,411,529$ & $21.41 \%$ \\
3: Sex & $(873,224)$ & $(52,389)$ & & & & \\
Education & $90.32 \%$ & $7.34 \%$ & 22,084 & & & \\
\hline
\end{tabular}




\section{Analysis}

The general expectation of our research could be summed up as: the higher the clarity of a cue, the easier it is for a voter to 'decode' the suggestion and follow it. On the contrary, blurred and ambiguous statements should result in a divided electorate. Model 1 in Table 2 shows the results for the analysis of compliance of voters with partisan cues regarding attending or abstaining from voting on the referendum. The coefficients show that high clarity of party recommendation (Clarity 1.) leads to higher responsiveness of voters, who follow the recommendation. Hence, when a party or its leadership issues an official statement with a clear position, it has a positive and significant effect on voters and their behavior as compared to parties that do not make such a statement or that only unofficially present the positions of the party leaders. On the other hand, we found no such effect for cases of party leaders who proclaimed an official position towards the turnout in the referendum but who were opposed by other party members (Clarity 2.). Our model thus shows that for the mobilization issue parties have to provide clear and unambiguous messages in order to affect their supporters. Lowering the clarity due to different stances presented by various party members rather confuses the voters, as they are given contradictory suggestions as to how they should act. 
Table 2. Probability of referendum attendance (Probit regression)

\begin{tabular}{|c|c|c|}
\hline & \multicolumn{2}{|c|}{ Model 1} \\
\hline & Coef. & $\mathbf{z}$ \\
\hline \multirow{2}{*}{ Clarity 1.} & $0.437 * * *$ & 3.10 \\
\hline & $(0.140)$ & \\
\hline \multirow{2}{*}{ Clarity 2.} & 0.090 & 0.69 \\
\hline & $(0.131)$ & \\
\hline Clarity 3. & \multicolumn{2}{|c|}{ Reference category } \\
\hline \multirow{2}{*}{ Faith } & $0.233 * * *$ & 4.81 \\
\hline & $(0.048)$ & \\
\hline \multirow{2}{*}{ Gender } & $-0.179 *$ & -1.83 \\
\hline & (0.098) & \\
\hline \multirow{2}{*}{ Age $(\log )$} & 0.096 & 0.70 \\
\hline & $(0.137)$ & \\
\hline \multirow{2}{*}{ Education } & $0.092 *$ & 1.75 \\
\hline & $(0.052)$ & \\
\hline \multirow{2}{*}{ Income } & $-0.005^{*}$ & -1.77 \\
\hline & $(0.003)$ & \\
\hline \multirow{2}{*}{ Constant } & $-1.567 * * *$ & -2.80 \\
\hline & $(0.560)$ & \\
\hline $\mathrm{N}$ & 713 & \\
\hline Loglikelihood & -464.083 & \\
\hline PseudoR2 & 0.060 & \\
\hline Prob>chi2 & 0.000 & \\
\hline LRchi2(7) & 59.38 & \\
\hline
\end{tabular}

Standard error in parentheses. $* \mathrm{p}<.1, * * \mathrm{p}<.05, * * * \mathrm{p}<.01$.

For a more straightforward interpretation of the effect of clarity of partisan cues we computed their average marginal effects (see Table 3). These provide information about the effect of a unit change in the explanatory variable on the change of probability that the outcome variable takes the value one, i.e. in our case the probability that the voters acted in accordance with the suggestion of their party. For the level of clarity 2 (i.e. official position of party leader opposed by other members) there is an increase of around three percent in voters following the recommendation, however this effect is without significance. More importantly, when parties make their statements officially and without any opposing messages, the average 
marginal effects increase the odds by more than 16 percent that voters will take the cue, and this effect is significant. These outcomes show that recommendations with a high level of clarity significantly and substantially increase the likelihood that parties will affect the behavior of their own supporters.

As for controls, we found that only the level of faith supports the willingness of voters to follow the partisan cues. The other control variables are found not to have such effects, although gender, education and income were significant on $p=0.1$ level. The coefficients for these three variables however show that the size of their effect is rather limited.

Table 3. Average marginal effects on compliance of voters with recommendation of their parties

\begin{tabular}{|c|c|c|}
\hline & \multicolumn{2}{|l|}{ Delta-method } \\
\hline & Dy/dx & $\mathbf{z}$ \\
\hline Clarity 1. & $\begin{array}{r}0.163 * * * \\
(0.051)\end{array}$ & 3.17 \\
\hline Clarity 2. & $\begin{array}{r}0.033 \\
(0.048)\end{array}$ & 0.69 \\
\hline Clarity 3. & Reference category & \\
\hline Faith & $\begin{array}{r}0.086 * * * \\
(0.017)\end{array}$ & 5.06 \\
\hline Gender & $\begin{array}{c}-0.066^{*} \\
(0.036)\end{array}$ & -1.84 \\
\hline Age $(\log )$ & $\begin{array}{r}0.035 \\
(0.051)\end{array}$ & 0.70 \\
\hline Education & $\begin{array}{c}0.034 * \\
(0.019)\end{array}$ & 1.76 \\
\hline Income & $\begin{array}{c}-0.002 * \\
(0.001) \\
\end{array}$ & -1.78 \\
\hline $\mathrm{N}$ & 713 & \\
\hline
\end{tabular}


We now turn to the results of the effect of clarity of partisan cues when it comes to actual voting in the referendum. In order to do so we computed two-stage probit models using the Heckman correction to ensure that the selection bias does not affect our findings. Models $2-$ 4 in Table 4 show the results. Compared to the issue of mobilization, we are faced with mixed results. For questions one and three in the Slovak referendum the clarity of partisan messages is found to be without significance. What is more, the actual effects for the highest level of clarity, i.e. clear and officially presented recommendations of parties, are found to be negative, while lower clarity - when some members oppose the official position of their leader - has a positive effect. In case of the second question in the referendum dealing with the adoption of children, both levels of clarity are significant and positive. Contrary to our expectation, however, a stronger positive effect is found for lower level clarity than for cues officially provided by parties as their only recommendation.

Among the control variables, the only one with a substantial effect is age. As the results in Models 2 and 3 in Table 4 show, older people tend to follow their party's suggestion to a greater extent, which could be interpreted in terms of their higher respect for (partisan) authorities. This effect was not, however, found in Model 5, which covers the third referendum question, and this limits our ability to generalize the role of age.

To conclude, in the case of mobilization, the partisan cues of a higher clarity increase the probability that voters will be (de)mobilized in accordance with the recommendation of the party. On the other hand, for the act of voting, no prevailing effect of clarity has been found - the analyses of the referendum questions revealed different (and sometimes even opposite) trends. The data indicates that the real political struggle in the 2015 'Family' referendum in Slovakia was therefore not which side to vote for, but rather whether to attend the popular vote at all. 
The most reasonable explanation seems to be the Slovak institutional setup. A referendum can become valid only when more than $50 \%$ of the electorate attend the voting. This condition leaves the 'no' camp with basically zero motivation to attend as long as the turnout does not seem like it will pass the threshold. This is the reason why the referendum turnout in 2015 fell to as low as $21.4 \%$, which is significantly below the numbers from national parliamentary or presidential elections, however it is far from unusual for referendums in Slovakia (see Nemčok \& Spáč, 2018). Voters who oppose the issue abstain from voting simply because abstention is even more effective than voting 'no', since it does not increase turnout to the level required for validity.

Therefore, the moment when a voter makes the decision to turn out for a referendum is already a moment when partisan cues play a crucial role. However, when voters within this institutional setup decide to disregard the recommendation of their party and attend a popular vote, their autonomy from the partisan cues is higher. Even though it may seem that a voter is voting in accordance with the partisan recommendation (Model 1), unlike mobilization, the clarity of the cue reveals no meaningful pattern (Models 2-4). This indicates that in a similar institutional setup, the ability of partisan cues to influence the shares of ballots cast for 'yes' or 'no' is lower, compared to their influence on turnout. This is an interesting finding, which emphasizes the fact that partisan cues should not be studied only in relation to voting but also as a strong determinant of turnout, especially in an institutional setup that sets high demands for the validity of a referendum, which is definitely the case for Slovakia. 
Table 4. Attendance and voting in the referendum (Probit models with Heckman selection)

\begin{tabular}{|c|c|c|c|c|c|c|}
\hline & \multicolumn{2}{|c|}{$\begin{array}{c}\text { Model 2 } \\
\text { Question 1: Marriage }\end{array}$} & \multicolumn{2}{|c|}{$\begin{array}{c}\text { Model 3 } \\
\text { Question 2: Adoption }\end{array}$} & \multicolumn{2}{|c|}{$\begin{array}{c}\text { Model } 4 \\
\text { Question 3: Sex education }\end{array}$} \\
\hline & Coef. & $\mathbf{z}$ & Coef. & $\mathbf{z}$ & Coef. & $\mathbf{Z}$ \\
\hline \multicolumn{7}{|c|}{ First stage: Compliance with party } \\
\hline Clarity 1. & $\begin{array}{l}-0.384 * \\
(0.216)\end{array}$ & -1.77 & $\begin{array}{r}0.927 * * * \\
(0.258)\end{array}$ & 3.59 & $\begin{array}{r}-0.021 \\
(0.206)\end{array}$ & -0.10 \\
\hline Clarity 2. & $\begin{array}{r}0.162 \\
(0.312)\end{array}$ & 0.52 & $\begin{array}{r}1.540 * * * \\
(0.363)\end{array}$ & 4.24 & $\begin{array}{r}0.201 \\
(0.262)\end{array}$ & 0.77 \\
\hline Clarity 3. & \multicolumn{2}{|c|}{ Reference category } & \multicolumn{2}{|c|}{ Reference category } & \multicolumn{2}{|c|}{ Reference category } \\
\hline Gender & $\begin{array}{r}-0.096 \\
(0.198)\end{array}$ & -0.48 & $\begin{array}{r}-0.095 \\
(0.199)\end{array}$ & -0.48 & $\begin{array}{r}-0.149 \\
(0.190)\end{array}$ & -0.79 \\
\hline Age $(\log )$ & $\begin{array}{r}0.556 * * \\
(0.256)\end{array}$ & 2.17 & $\begin{array}{l}0.703 * \\
(0.364)\end{array}$ & 1.93 & $\begin{array}{r}0.381 \\
(0.309)\end{array}$ & 1.23 \\
\hline Education & $\begin{array}{r}0.013 \\
(0.097)\end{array}$ & 0.13 & $\begin{array}{l}-0.075 \\
(0.099)\end{array}$ & -0.76 & $\begin{array}{l}-0.151 \\
(0.093)\end{array}$ & -1.62 \\
\hline Income & $\begin{array}{r}-0.005 \\
(0.006)\end{array}$ & -0.79 & $\begin{array}{r}0.000 \\
(0.007)\end{array}$ & 0.11 & $\begin{array}{l}-0.001 \\
(0.006)\end{array}$ & -0.30 \\
\hline Constant & $\begin{array}{r}-0.310 \\
(1.004) \\
\end{array}$ & -0.31 & $\begin{array}{r}-2.293 \\
(1.727) \\
\end{array}$ & -1.33 & $\begin{array}{r}0.072 \\
(1.334) \\
\end{array}$ & 0.05 \\
\hline \multicolumn{7}{|c|}{ Second stage: Participation in referendum } \\
\hline Faith & $\begin{array}{r}0.278 * * * \\
(0.054)\end{array}$ & 5.07 & $\begin{array}{r}0.272 * * * \\
(0.061)\end{array}$ & 4.40 & $\begin{array}{r}0.277 * * * \\
(0.060)\end{array}$ & 4.55 \\
\hline Gender & $\begin{array}{r}-0.021 \\
(0.129)\end{array}$ & -0.17 & $\begin{array}{r}-0.026 \\
(0.130)\end{array}$ & -0.20 & $\begin{array}{l}-0.023 \\
(0.130)\end{array}$ & -0.18 \\
\hline Age $(\log )$ & $\begin{array}{r}0.357 * * \\
(0.180)\end{array}$ & 1.98 & $\begin{array}{r}0.382 * * \\
(0.183)\end{array}$ & 2.08 & $\begin{array}{r}0.366 * * \\
(0.182)\end{array}$ & 2.00 \\
\hline Education & $\begin{array}{r}0.074 \\
(0.067)\end{array}$ & 1.10 & $\begin{array}{r}0.079 \\
(0.068)\end{array}$ & 1.16 & $\begin{array}{r}0.077 \\
(0.068)\end{array}$ & 1.14 \\
\hline Income & $\begin{array}{r}-0.002 \\
(0.004)\end{array}$ & -0.71 & $\begin{array}{r}-0.002 \\
(0.004)\end{array}$ & -0.63 & $\begin{array}{r}-0.002 \\
(0.004)\end{array}$ & -0.59 \\
\hline Constant & $\begin{array}{r}-2.566 * * * \\
(0.719) \\
\end{array}$ & -3.56 & $\begin{array}{r}-2.656 * * * \\
(0.734) \\
\end{array}$ & -3.62 & $\begin{array}{r}-2.607 * * * \\
(0.733) \\
\end{array}$ & -3.56 \\
\hline $\mathrm{N}$ (uncensored $\mathrm{N}$ ) & $416(201)$ & & $416(201)$ & & $416(201)$ & \\
\hline Wald chi2 (6) & 10.42 & & 22.35 & & 6.09 & \\
\hline Rho & $\begin{array}{r}-0.998 \\
(0.233)\end{array}$ & & $\begin{array}{r}-0.455 \\
(0.430)\end{array}$ & & $\begin{array}{r}-0.554 \\
(0.339)\end{array}$ & \\
\hline Atanh rho & $\begin{array}{r}-3.464 \\
(59.737)\end{array}$ & & $\begin{array}{r}-0.492 \\
(0.543)\end{array}$ & & $\begin{array}{r}-0.624 \\
(0.490)\end{array}$ & \\
\hline Log likelihood & -339.315 & & -371.710 & & -377.747 & \\
\hline Prob > chi2 & 0.108 & & 0.001 & & 0.413 & \\
\hline $\begin{array}{l}\text { LR test of indep } \\
\text { Prob }>\text { chi } 2\end{array}$ & 0.024 & & 0.366 & & 0.198 & \\
\hline
\end{tabular}

Standard error in parentheses. $* \mathrm{p}<.1, * * \mathrm{p}<.05, * * * \mathrm{p}<.01$. 


\section{Conclusion}

In a certain institutional setup, when a high threshold is required to achieve the validity of a referendum result, the legitimate strategy of a 'no' camp is to abstain from voting. However, published studies have mostly perceived a referendum only as an act of voting either 'yes' or ‘no’ (Cini, 2004; Franklin, Marsh, \& McLaren, 1994; Franklin, Marsh, \& Wlezien, 1994; Hobolt, 2006, 2007; Hug \& Sciarini, 2000; Pettersen et al., 1996; Pierce et al., 1983) and have not paid sufficient attention to the factors driving voters' decisions to attend or abstain from voting. Likewise, partisan cues have been found to be one of the main forces driving voter behavior and their impact on mobilization has remained mostly neglected, even though its impact on a referendum's success can easily become crucial.

This study attempted to examine the impact of partisan cues on the mobilization of voters in a referendum and add a valuable extension to the body of literature dedicated to the influence of partisan cues. For this purpose, we ran a set of statistical operations on data gathered in a representative public survey conducted before the 2015 'Family' referendum in Slovakia. This referendum constitutes a great case because it kept possible intervening institutional factors constant and, additionally, the rather controversial topic related to the rights of sexual minorities caused some parties to hesitate in taking a clear stance, which allowed us to study the effects of cues on the various levels of their clarity.

Our statistical models provides compelling evidence that partisan cues related to mobilization are a force shaping voters' decisions to attend or abstain from a referendum in a similar fashion compared to recommendations of which side to vote for. Thus, the low turnout of $21.4 \%$ in the 2015 'Family' referendum cannot be perceived only as a sign of people's lack of interest. This group also includes members for whom the abstention was a legitimate political decision based on the recommendation of their preferred party, which, unlike a 'no' vote, does not help to increase turnout beyond the validity threshold. 
At the same time, the clearer the (de)mobilizing recommendation is, the stronger the effect is. Therefore, if parties want to utilize the popular vote to improve their own position in the political struggles, one viable strategy is to take a clear stance. The available data however do not allow us to know whether parties expect their supporters to better accept and follow more clear recommendations, which in turn would stimulate the parties to produce statements with higher clarity. The motivations of parties to express their recommendation either in a clear or a rather blurry fashion thus remains a topic for further study.

However, higher clarity resulting in a bigger effect does not apply to how people vote. The various levels of clarity brought various (and sometimes contradictory) results. This suggests that if a voter decides to vote, despite a restrictive institutional setup similar to Slovakia's, the influence of the party's cue is lower. Therefore, and most importantly for the future studies of partisan cues, in an institutional setup that requires a high turnout threshold for validity, a party's recommendation related to mobilization becomes even more crucial for the referendum outcome than an endorsement of which side to vote for.

Further research should validate the presented results on additional cases. If the conclusions are successfully replicated, a more complex assessment of the influence of partisan cues on referendum voting will need to be developed. The sole focus on voting seems to be insufficient. The decision making must be examined in a wider institutional framework that determines the impact of parties on voter behavior under the institutions of direct democracy. 


\section{References}

Adamczyk, A., \& Pitt, C. (2009). Shaping attitudes about homosexuality: The role of religion and cultural context. Social Science Research, 38(2), 338-351. https://doi.org/10.1016/j.ssresearch.2009.01.002

Altman, D. (2011). Direct Democracy Worldwide. Cambridge: Cambridge University Press.

Andersen, R., Tilley, J., \& Heath, A. F. (2005). Political Knowledge and Enlightened Preferences: Party Choice Through the Electoral Cycle. British Journal of Political Science, 35(2), 285-302. https://doi.org/10.1017/S0007123405000153

Arceneaux, K. (2005). Do Campaigns Help Voters Learn? A Cross-National Analysis. British Journal of Political Science, 36(1), 159-173. https://doi.org/10.1017/S0007123406000081

Besen, Y., \& Zicklin, G. (2007). Young Men, Religion and Attitudes towards Homosexuality. Journal of Men, Masculinities and Spirituality, 1(3), 250-266.

Bodenstein, T., \& Kemmerling, A. (2011). Ripples in a Rising Tide: Why Some EU Regions Receive More Structural Funds than Others. European Integration Online Papers, 16. https://doi.org/10.1695/2011007

Borges, W., \& Clarke, H. D. (2008). Cues in Context: Analyzing the Heuristics of Referendum Voting with an Internet Survey Experiment. Journal of Elections, Public Opinion and Parties, 18(4), 433-448. https://doi.org/10.1080/17457280802305243

Brewer, P. R. (2003). The Shifting Foundations of Public Opinion about Gay Rights. The Journal of Politics, 65(4), 1208-1220. https://doi.org/10.1111/1468-2508.t01-1-00133

Camp, B. J. (2008). Mobilizing the Base and Embarrassing the Opposition: Defense of Marriage Referenda and Cross-Cutting Electoral Cleavages. Sociological Perspectives, 51(4), 713-733. https://doi.org/10.1525/sop.2008.51.4.713

Cini, M. (2004). Culture, Institutions and Campaign Effects: Explaining the Outcome of Malta's EU Accession Referendum. West European Politics, 27(4), 584-602. https://doi.org/10.1080/0140238042000249911

Cuprik, R. (2014, December 8). President sets date for 'family' referendum. The Slovak Spectator. Retrieved from https://spectator.sme.sk/c/20052872/president-sets-date-forfamily-referendum.html

De Vreese, C. H., \& Semetko, H. A. (2004). Political Campaigning in Referendums: Framing the Referendum Issue. London: Routledge.

Font, J., \& Rodríguez, E. (2009). Intense but useless? Public debate and voting factors in two referendums in Spain. In M. Setälä \& T. Schiller (Eds.), Referendums and Representative 
Democracy. Responsiveness, accountability and deliberation (pp. 341-352). London and New York: Routledge.

Franklin, M. N., Marsh, M., \& McLaren, L. (1994). Uncorking the Bottle: Popular Opposition to European Unification in the Wake of Maastricht. Journal of Common Market Studies, 32(4), 455-472. https://doi.org/10.1111/j.1468-5965.1994.tb00509.x

Franklin, M. N., Marsh, M., \& Wlezien, C. (1994). Attitudes toward Europe and referendum votes: A response to Siune and Svensson. Electoral Studies, 13(2), 117-121.

Franklin, M. N., van der Eijk, C., \& Marsh, M. (1995). Referendum outcomes and trust in government: Public support for Europe in the wake of Maastricht. West European Politics, 18(3), 101-117. https://doi.org/10.1080/01402389508425093

Gherghina, S. (2018). How Political Parties use Referendums in Eastern Europe: Exploring Analytical Dimensions. East European Politics and Societies.

Gherghina, S., \& Miscoiu, S. (2013). The Failure of Cohabitation: Explaining the 2007 and 2012 Institutional Crises in Romania. East European Politics \& Societies, 27(4), 668684.

Glaurdić, J., \& Vuković, V. (2016). Proxy Politics, Economic Protest, or Traditionalist Backlash: Croatia's Referendum on the Constitutional Definition of Marriage. Europe Asia Studies, 68(5), 803-825. https://doi.org/10.1080/09668136.2016.1186610

Haider-Markel, D. P., \& Joslyn, M. R. (2005). Attributions and the Regulation of Marriage: Considering the Parallels Between Race and Homosexuality. PS: Political Science \& Politics, 38(02), 233-239. https://doi.org/10.1017/S1049096505056362

Heckman, J. J. (1979). Sample Selection Bias as a Specification Error. Econometrica, 47(1), $153-161$.

Hobolt, S. B. (2005). When Europe matters : The impact of political information on voting behaviour in EU referendums. Journal of Elections, Public Opinion \& Parties, 15(1), 85-109. https://doi.org/10.1080/13689880500064635

Hobolt, S. B. (2006). How Parties Affect Vote Choice in European Integration Referendums. Party Politics, 12(5), 623 -647. https://doi.org/10.1177/1354068806066791

Hobolt, S. B. (2007). Taking cues on Europe? Voter competence and party endorsements in referendums on European integration. European Journal of Political Research, 46(2), 151-182. https://doi.org/10.1111/j.1475-6765.2006.00688.x

Hug, S. (2003). Selection Bias in Comparative Research: The Case of Incomplete Data Sets. Political Analysis, 11(03), 255-274. https://doi.org/10.1093/pan/mpg014

Hug, S., \& Sciarini, P. (2000). Referendums on European Integration: Do Institutions Matter 
in the Voter's Decision? Comparative Political Studies, 33(1), 3-36.

https://doi.org/doi:10.1177/0010414000033001001

Jenssen, A. T., \& Listhaug, O. (2001). Voters' Decisions in the Nordic EU Referendums of 1994: the Importance of Party Cues. In M. Mendelsohn \& A. Parkin (Eds.), Referendum Democracy: Citizens, Elites and Deliberation in Referendum Campaigns (pp. 169-190). Basingstoke: Palgrave Macmillan UK.

Kováč, P. (2015, February 10). Aliancii dala peniaze aj cirkev. Na kampaň išli desat'tisíce eur. [Alliance received money also from the Curch. Tens of thousands were spent on the campaing.]. Hospodárske Noviny Online. Retrieved from https://dennik.hnonline.sk/slovensko/552508-aliancii-dala-peniaze-aj-cirkev-na-kampanisli-desattisice-eur

Kriesi, H. (2005). Direct Democratic Choice: The Swiss Experience. Plymouth: Lexington Books.

LeDuc, L. (2009). Campaign tactics and outcomes in referendums: a comparative analysis. In M. Setälä \& T. Schiller (Eds.), Referendums and Representative Democracy: Responsiveness, accountability and deliberation (pp. 139-161). London, New York: Routledge.

Lupia, A., \& Johnston, R. (2001). Are Voters to Blame? Voter Competence and Elite Maneuvers in Referendums. In Referendum Democracy (pp. 191-210). London: Palgrave Macmillan UK. https://doi.org/10.1057/9781403900968_10

Lupia, A., \& McCubbins, M. D. (1998). The Democratic Dilemma: Can Citizens Learn What They Need to Know? Cambridge: Cambridge University Press.

McKelvey, R. D., \& Ordeshook, P. C. (1986). Information, Electoral Equilibria, and the Democratic Ideal. The Journal of Politics, 48(4), 909-937.

McVeigh, R., \& Diaz, M.-E. D. (2009). Voting to Ban Same-Sex Marriage: Interests, Values, and Communities. American Sociological Review, 74(6), 891-915.

Nemčok, M., \& Spáč, P. (2018). Referendum as a Party Tool: The Case of Slovakia. East European Politics \& Societies.

Pettersen, P. A., Jenssen, A. T., \& Listhaug, O. (1996). The 1994 EU Referendum in Norway: Continuity and Change. Scandinavian Political Studies, 19(3), 257-281. https://doi.org/10.1111/j.1467-9477.1996.tb00393.x

Pierce, R., Valen, H., \& Listhaug, O. (1983). Referendum Voting Behavior: The Norwegian and British Referenda on Membership in the European Community. American Journal of Political Science, 27(1), 43-63. https://doi.org/10.2307/2111052 
Rovny, J. (2012). Who Emphasizes and Who Blurs? Party Strategies in Multidimensional Competition. European Union Politics, 13(2), 269-292. https://doi.org/10.1177/1465116511435822

Rybáŕ, M., \& Šovčíková, A. (2016). The 2015 Referendum in Slovakia. East European Quarterly, 44(1-2), 79-88.

Sager, F., \& Bühlmann, M. (2009). Checks and balances in Swiss direct democracy. In M. Setälä \& T. Schiller (Eds.), Referendums and Representative Democracy. Responsiveness, accountability and deliberation (pp. 186-206). London and New York: Routledge.

Silagadze, N., \& Gherghina, S. (2017). When who and how matter: explaining the success of referendums in Europe. Comparative European Politics, 1-18. https://doi.org/10.1057/s41295-017-0107-9

Smrek, M. (2015, March 4). The Failed Slovak Referendum on "Family": Voters' Apathy and Minority Rights in Central Europe. Balticworlds.Com. Retrieved from http://balticworlds.com/the-failed-slovak-referendum-on-"family"/

Spáč, P. (2010). Priama a zastupitel'ská demokracia na Slovensku: Volebné reformy a referendá po roku 1989 [Direct and representative democracy in Slovakia: Electoral reforms and referendums held after 1989]. Brno: Centrum pro studium demokracie a kultury.

Statistical Office of the Slovak Republic. (2011). Population Census 2011. Retrieved from https://census2011.statistics.sk/

Stevenson, R. T., \& Vavreck, L. (2000). Does campaign length matter? Testing for crossnational effects. British Journal of Political Science, 30(2), 217-235. https://doi.org/10.1017/S0007123400000107

Zaller, J. (1992). The Nature and Origins of Mass Opinion. Cambridge: Cambridge University Press. 


\section{Appendix A: Positions of the parties}

Table A.1. Coding of the party recommendations and recommendation clarity

\begin{tabular}{|c|c|c|c|c|c|c|c|c|c|}
\hline \multirow[b]{2}{*}{ Party } & \multirow[b]{2}{*}{ Abb. } & \multicolumn{2}{|c|}{ Attendance } & \multicolumn{4}{|c|}{ Questions } & \multirow{2}{*}{\multicolumn{2}{|c|}{ Sources }} \\
\hline & & $\begin{array}{c}\text { Recom- } \\
\text { mendation }\end{array}$ & Clarity* & $\begin{array}{l}\text { 1: Recom- } \\
\text { mendation }\end{array}$ & $\begin{array}{l}\text { 2: Recom- } \\
\text { mendation }\end{array}$ & $\begin{array}{l}\text { 3: Recom- } \\
\text { mendation }\end{array}$ & Clarity* & & \\
\hline \multirow{2}{*}{$\begin{array}{l}\text { Christian Democratic } \\
\text { Movement }\end{array}$} & \multirow{2}{*}{$\mathrm{KDH}$} & \multirow{2}{*}{ Yes } & \multirow{2}{*}{1} & \multirow{2}{*}{ Yes } & \multirow{2}{*}{ Yes } & \multirow{2}{*}{ Yes } & \multirow{2}{*}{1} & Attendance: & Christian Democratic Movement 2014 \\
\hline & & & & & & & & Answers: & Christian Democratic Movement 2014 \\
\hline \multirow{2}{*}{ Communist Party of Slovakia } & \multirow{2}{*}{ KSS } & \multirow{2}{*}{ No } & \multirow{2}{*}{1} & \multirow{2}{*}{ No } & \multirow{2}{*}{ No } & \multirow{2}{*}{ No } & \multirow{2}{*}{1} & Attendance: & Communist Party of Slovakia 2014 \\
\hline & & & & & & & & Answers: & Communist Party of Slovakia 2014 \\
\hline \multirow{2}{*}{ People's Party Our Slovakia } & \multirow{2}{*}{ L'SNS } & \multirow{2}{*}{ Yes } & \multirow{2}{*}{1} & \multirow{2}{*}{ N/A } & \multirow{2}{*}{ N/A } & \multirow{2}{*}{ N/A } & \multirow{2}{*}{ N/A } & Attendance: & The News Agency of the Slovak Republic 2015b \\
\hline & & & & & & & & Answers: & N/A \\
\hline \multirow{2}{*}{ Most-Híd } & \multirow{2}{*}{ Most-Híd } & Yes & 3 & Yes & Yes & Yes & 3 & & $\begin{array}{l}\text { Jancová and Slovak News Agency, 2015; Pravda, } \\
2015\end{array}$ \\
\hline & & res & 3 & res & res & res & 3 & Answers: & $\begin{array}{l}\text { Jancová and Slovak News Agency, 2015; Pravda, } \\
2015\end{array}$ \\
\hline New Maiority & NOVA & Yes & 1 & Yes & Yes & Yes & 3 & Attendance: & New Majority 2015 \\
\hline ivew ivrajomity & 1NUVA & res & 1 & res & res & Ies & 3 & Answers: & Jancová and Slovak News Agency 2015 \\
\hline Ordinary People and & חי & Yes & 2 & Yes & Yes & Yes & 2 & Attendance: & Jancová and Slovak News Agency 2015 \\
\hline Independent Personalities & 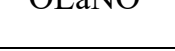 & $10 \mathrm{~s}$ & 2 & $1 \mathrm{Cs}$ & $1 \mathrm{Cs}$ & $1 \mathrm{Cs}$ & 2 & Answers: & Jancová and Slovak News Agency 2015 \\
\hline Frodomond Colidoritu & $\mathrm{CoC}$ & No & 1 & No & No & No & 1 & Attendance: & $\begin{array}{l}\text { Freedom and Solidarity 2014; Slovak News } \\
\text { Agency, } 2014\end{array}$ \\
\hline Freedom and solidarity & Sas & No & 1 & No & No & No & 1 & Answers: & Freedom and Solidarity 2014; Slovak News \\
\hline & & & & & & & & Answers. & Agency, 2014 \\
\hline $\begin{array}{l}\text { Slovak Democratic and } \\
\text { Christian Union - }\end{array}$ & SDKÚ-DS & Yes & 1 & N/A & N/A & N/A & N/A & Attendance: & $\begin{array}{l}\text { Slovak Democratic and Christian Union - } \\
\text { Democratic Party } 2015\end{array}$ \\
\hline Democratic Party & & & & & & & & Answers: & N/A \\
\hline \#Siet' & \#Siet' & Yes & 3 & Yes & $\mathrm{No}$ & Yes & 3 & Attendance: & Jancová and Slovak News Agency 2015 \\
\hline \#SIel & HDIel & res & 3 & res & NO & res & 3 & Answers: & Jancová and Slovak News Agency 2015 \\
\hline Smer-Social Democracy & Smer_SD & Yes & 2 & $\mathrm{~N} / \mathrm{A}$ & $\mathrm{N} / \mathrm{A}$ & $\mathrm{N} / \mathrm{A}$ & N/A & Attendance: & Cuprik, 2014 \\
\hline 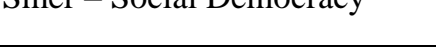 & 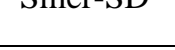 & 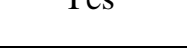 & 2 & 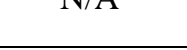 & $10 / \pi$ & $10 / \pi$ & $10 / \pi$ & Answers: & Cuprik, 2014 \\
\hline Party of the Hungarian & SMK & Yes & 2 & Yec & Yes & Yes & 2 & Attendance: & Slovak News Agency, 2015 \\
\hline Community & Sivin & res & 2 & Ies & Ies & Ies & 2 & Answers: & Slovak News Agency, 2015 \\
\hline Slovak National Party & SNS & Yes & 1 & Yes & Yes & Yes & 1 & Attendance: & Slovak National Party, 2014, 2015a \\
\hline Siovan Talionial 1 aity & & $10 \mathrm{~s}$ & 1 & & & & & Answers: & Slovak National Party, 2014, 2015a \\
\hline
\end{tabular}

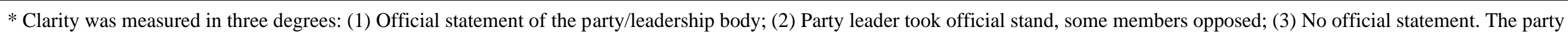
leader unofficially shared his/her stance with the media (without any confirmation from the internally divided party base);

Note: Sources are listed on the right side of the table respectively; compiled by authors 


\section{References}

Christian Democratic Movement. (2014, December 14). Stanovisko Rady KDH k referendu o rodine [Position of the KDH Council regarding the fimily referendum]. Retrieved from http://www.cestaplus.sk/cestaplus/clanok/stanovisko-rady-kdh-k-referendu-o-rodine

Communist Party of Slovakia. (2014). Stanovisko KSS k referendu o rodine [Position of the KSS regarding the 'Family' Referendum]. Retrieved from http://kss.sk/udalosti/vyhlasenia-a-stanoviska/1252-stanovisko-kss-k-referendu-orodine.html

Cuprik, R. (2014, December 8). President sets date for 'family' referendum. The Slovak Spectator. Retrieved from https://spectator.sme.sk/c/20052872/president-sets-date-forfamily-referendum.html

Freedom and Solidarity. (2014, October 28). SaS: Nezmyselné referendum, namierené voči konkrétnej menšine, by sa konat' nemalo. [SaS: Meaningless referendum aimed against a certain minority should not take place.]. Retrieved from http://www.strana-sas.sk/sasnezmyselne-referendum-namierene-voci-konkretnej-mensine-by-sa-konat-nemalo/3075

Jancová, D. \& Slovak News Agency. (2015, January 19). Referendum je problém aj pre krest'anské strany. Siet' a Obyčajní sa delia. [Referendum constitutes a problem also for christian parties. Siet' and Ordinary people are divided.]. Denník Sme. Retrieved from https://domov.sme.sk/c/7596953/referendum-je-problem-aj-pre-krestanske-strany-siet-aobycajni-sa-delia.html\#ixzz4g1A0TRFi

New Majority. (2015, January 24). NOVA odporúča íst' na referendum a schladit' vášne. [NOVA recommends to attend the referendum and calm down the passion.]. Retrieved from https://www.nova.sk/nova-odporuca-ist-na-referendum-a-schladit-vasne

Pravda. (2015, January 15). Smer sa postavil k referendu vyhýbavo. [Smer is avoiding the referendum.]. Pravda. Retrieved from https://spravy.pravda.sk/domace/clanok/342414smer-sa-postavil-k-referendu-vyhybavo/

Slovak Democratic and Christian Union - Democratic Party. (2015). Nemali by sme spochybňovat' inštitút referenda. [We should not question the referendum as an institution.]. Retrieved from http://www.sdku-ds.sk/c/20/nemali-by-sme-spochybnovatinstitut-referenda

Slovak National Party. (2014, December 1). Anton Hrnko: Referendum o rodine nezasiahne do práv žiadnej menšiny. [Anton Hrnko: The family referendum does not affect rights of any minority.]. Retrieved from http://www.sns.sk/aktuality/anton-hrnko-referendum-orodine-nezasiahne-do-prav-ziadnej-mensiny/ 
Slovak National Party. (2015, January 2). Andrej Danko: Podporujeme referendum o ochrane rodiny. [Andrej Danko: We support the family protection referendum.]. Retrieved from http://www.sns.sk/aktuality/andrej-danko-podporujeme-referendum-o-ochrane-rodiny/

Slovak News Agency. (2014, December 18). Referendum o rodine je úplne zbytočné, rozhorčil sa Sulík. [The Family Referendum is Completely Pointless, Sulík said]. Retrieved from https://www.webnoviny.sk/referendum-o-rodine-je-uplne-zbytocnerozhorcil-sa-sulik/

Slovak News Agency. (2015, January 3). Kukan, Flašíková, Sulík a Zala odmietajú referendum o rodine. [Kukan, Flašíková, Sulík a Zala oppose the 'Family' Referendum.]. Retrieved from https://domov.sme.sk/c/7571715/kukan-flasikova-sulik-a-zala-odmietajureferendum-o-rodine.html\#ixzz4g1HgczI5

The News Agency of the Slovak Republic. (2015, January 21). Predseda BBSK Marian Kotleba pozval najvyšších ústavných činitel'ov na Úrad BBSK [Chairman of the Banská Bystrica self-governing region (BBSK) invited the highest constitutional officials to the BBSK]. Retrieved from http://www.tasr.sk/ots/ots-predseda-bbsk-marian-kotlebapozval/19571-clanok.html 


\section{Online Appendix B: Party supporters and their declared turnout}

Table B.1. Share of party supporters in the sample and their declared probability to attend the referendum (in \%)

\begin{tabular}{|c|c|c|c|c|c|c|c|c|c|c|c|c|c|}
\hline \multirow{2}{*}{ Party } & & \multirow{2}{*}{$\begin{array}{l}\text { Total party } \\
\text { support }\end{array}$} & \multicolumn{11}{|c|}{ Declared probability to attend the referendum } \\
\hline & & & $0 \%$ & $10 \%$ & $20 \%$ & $30 \%$ & $40 \%$ & $\mathbf{5 0 \%}$ & $60 \%$ & $70 \%$ & $80 \%$ & $90 \%$ & $100 \%$ \\
\hline Christian Democratic Movement (KDH) & $\mathrm{N}=81$ & 7.57 & 4.9 & 0.0 & 1.2 & 0.0 & 2.5 & 11.1 & 4.9 & 4.9 & 11.1 & 17.3 & 42.0 \\
\hline Communist Party of Slovakia (KSS) & $\mathrm{N}=11$ & 1.03 & 36.4 & 0.0 & 0.0 & 9.1 & 9.1 & 9.1 & 0.0 & 0.0 & 18.2 & 9.1 & 9.1 \\
\hline People's Party Our Slovakia (LSNS) & $\mathrm{N}=11$ & 1.03 & 27.3 & 9.1 & 0.0 & 0.0 & 0.0 & 18.2 & 0.0 & 9.1 & 9.1 & 9.1 & 18.2 \\
\hline Most-Híd & $\mathrm{N}=53$ & 4.95 & 7.5 & 9.4 & 11.3 & 9.4 & 1.9 & 17.0 & 9.4 & 1.9 & 17.0 & 7.5 & 7.5 \\
\hline New Majority (NOVA) & $\mathrm{N}=20$ & 1.87 & 10.0 & 5.0 & 0.0 & 0.0 & 0.0 & 30.0 & 5.0 & 15.0 & 15.0 & 10.0 & 10.0 \\
\hline $\begin{array}{l}\text { Ordinary People and Independent } \\
\text { Personalities (OLaNO) }\end{array}$ & $\mathrm{N}=56$ & 5.23 & 26.8 & 0.0 & 5.4 & 5.4 & 1.8 & 21.4 & 1.8 & 7.1 & 1.8 & 8.9 & 19.6 \\
\hline Freedom and Solidarity (SaS) & $\mathrm{N}=32$ & 2.99 & 21.9 & 0.0 & 6.3 & 3.1 & 9.4 & 12.5 & 6.3 & 3.1 & 12.5 & 6.3 & 18.8 \\
\hline $\begin{array}{l}\text { Slovak Democratic and Christian Union - } \\
\text { Democratic Party (SDKÚ-DS) }\end{array}$ & $\mathrm{N}=28$ & 2.62 & 10.7 & 3.6 & 0.0 & 3.6 & 7.1 & 17.9 & 10.7 & 10.7 & 3.6 & 7.1 & 25.0 \\
\hline \#Siet' & $\mathrm{N}=84$ & 7.85 & 16.7 & 3.6 & 7.1 & 4.8 & 3.6 & 20.2 & 1.2 & 4.8 & 13.1 & 9.5 & 15.5 \\
\hline Smer - Social Democracy & $\mathrm{N}=259$ & 24.21 & 17.8 & 5.4 & 4.6 & 5.0 & 2.3 & 16.2 & 3.5 & 7.3 & 5.4 & 8.9 & 23.6 \\
\hline Party of the Hungarian Community (SMK) & $\mathrm{N}=38$ & 3.55 & 21.1 & 2.6 & 5.3 & 7.9 & 0.0 & 10.5 & 7.9 & 5.3 & 10.5 & 13.2 & 15.8 \\
\hline Slovak National Party (SNS) & $\mathrm{N}=42$ & 3.93 & 16.7 & 4.8 & 2.4 & 0.0 & 2.4 & 16.7 & 7.1 & 2.4 & 9.5 & 9.5 & 28.6 \\
\hline Overall (supporters of parties above) & $\mathrm{N}=715$ & - & 16.4 & 3.9 & 4.6 & 4.3 & 2.8 & 16.5 & 4.5 & 6.0 & 8.8 & 9.9 & 22.2 \\
\hline Overall & $\mathrm{N}=1070$ & - & 21.1 & 5.4 & 5.0 & 5.0 & 3.5 & 14.6 & 5.1 & 5.7 & 8.1 & 8.5 & 17.9 \\
\hline
\end{tabular}




\section{Appendix C: Religious faith as a proxy for homophobia}

In the main body of the article, we use the strength of an individual's religious faith as proxy for homophobia in the analysis. This part of the appendix offers two arguments for why such a procedure is justifiable.

Firstly, the link between religion and homophobic attitudes is well examined in current literature (e.g. Brewer, 2003; Haider-Markel \& Joslyn, 2005; Whitehead, 2010), where those who consider themselves religious or attend religious services more often express more homophobic attitudes towards homosexuality in general and oppose same-sex marriage and gay rights more strongly in particular.

Secondly, the relationship between homophobia and religious faith in Slovakia can be assessed empirically. Using data from the third wave of the European Value Survey (EVS), we found a significant correlation between several measures of religious faith and attitudes towards homosexuals. We use the variables "Q1F: how important in your life: religion" (4 point scale ranging from 1 - very important to 4 - not at all important), “Q25: how often attend religious services" ( 7 point scale ranging from 1 - more than once week to 7 - never, practically never), "Q36: how important is God in your life” (10 point scale ranging from 1 very important to 4 - not at all important), "Q6L: don't like as neighbours: homosexuals" (dichotomous variable, 0 - not mentioned, 1 - mentioned), “Q47C: homosexual couples - can adopt children" (5 point scale ranging from 1 - agree strongly to 5 - disagree strongly), “Q68H: do you justify: homosexuality” (10 point scale ranging from 1 - never to 10 always). Associations between all variables except “Q6L: don't like as neighbours: homosexuals" are measured by spearman correlation, as all these variables can be considered ordinal. Association of "religious variables" and homosexual neighbours is measured by contingency coefficient, more specifically by Cramer's V.

The results of analysis reflect findings in the cited literature. Those who attend religious services more often as well as those who consider God to be important in their life 
and also consider themselves as religious are less tolerant of homosexuality, as they express more often than others that they do not want a homosexual person as a neighbor. More strongly religious people also more strongly oppose the possibility for same-sex couples to adopt children and also consider homosexuality as less justifiable than less religious citizens.

Table C.1. Spearman correlation between variables measuring religion and homophobia (EVS 2008)

\begin{tabular}{|c|c|c|c|c|}
\hline & $\begin{array}{c}\text { God important in } \\
\text { life }\end{array}$ & $\begin{array}{c}\text { Attend religious } \\
\text { services }\end{array}$ & $\begin{array}{l}\text { Homosexual } \\
\text { adopt children }\end{array}$ & $\begin{array}{c}\text { Justify } \\
\text { homosexuality }\end{array}$ \\
\hline Religion important in life & $-0.718 * *$ & $0.720 * *$ & $-0.177 * *$ & $0.255^{* *}$ \\
\hline God important in life & & $-0.725 * *$ & $0.148 * *$ & $-0.217 * *$ \\
\hline attend religious services & & & $-0.169 * *$ & $0.227 * *$ \\
\hline homosexual adopt children & & & & $-0.183 * *$ \\
\hline
\end{tabular}

** Correlation is significant at the 0.01 level (2-tailed).

$\mathrm{N}=1150$

Table C.2. Cramer's V between variables measuring religion and homophobia (EVS 2008)

\begin{tabular}{lr}
\hline & $\begin{array}{c}\text { Don't like as neighbours: } \\
\text { homosexuals }\end{array}$ \\
\hline Religion important in life & $0.194 * *$ \\
God important in life & $0.180^{* *}$ \\
Attend religious services & $0.167 * *$ \\
\hline$*$ Correlation is significant at the 0.01 level (2-tailed).
\end{tabular}

\section{References}

Brewer, P.R. (2003). The Shifting Foundations of Public Opinion about Gay Rights. The Journal of Politics 65(4): 1208-1220.

Haider-Markel, D.P. \& Joslyn, M.R. (2005). Attributions and the Regulation of Marriage: Considering the Parallels Between Race and Homosexuality. PS: Political Science \& Politics 38(02): 233-239.

Whitehead, A.L. (2010). Sacred Rites and Civil Rights: Religion's Effect on Attitudes Toward Same-Sex Unions and the Perceived Cause of Homosexuality. Social Science Quarterly 91(1): 63-79. 
